\title{
Rheumatic Diseases Presenting with Guillain-Barré Syndrome: Sjögren's Syndrome and Systemic Lupus Erythematosus
}

\author{
Guillain-Barré Sendromu ile Prezente Olan Romatolojik Hastalıklar: Sjögren \\ Sendromu ve Sistemik Lupus Eritematozus
}

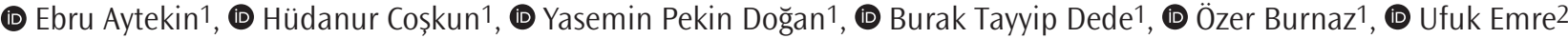 \\ 1University of Health Sciences Turkey, İstanbul Training and Research Hospital, Clinic of Physical Medicine and Rehabilitation, i̇stanbul, Turkey \\ 2University of Health Sciences Turkey, İstanbul Training and Research Hospital, Clinic of Neurology, İstanbul, Turkey
}

\begin{abstract}
The coexistence of Guillain-Barré syndrome (GBS) with autoimmune rheumatic diseases is extremely rare. In addition to flu, infection, trauma, vaccination, blood transfusion, chemotherapy and surgical intervention, rheumatic diseases may be the underlying etiological cause of resistant and prolonged GBS cases. Therefore, appropriate treatments specific to rheumatic diseases may accelerate the healing process, reduce the possibility of neurological sequelae and greatly contribute to the rehabilitation process.
\end{abstract}

Keywords: Guillain-Barré syndrome, rehabilitation, rheumatic diseases, systemic lupus erythematosus, Sjögren syndrome

\section{ÖZ}

Guillain-Barré sendromu (GBS) ile otoimmün romatolojik hastalıkların birlikteliği oldukça nadirdir. Gribal enfeksiyon, travma, aşılama, kan transfüzyonu, kemoterapi ve cerrahi girișim yanında dirençli ve uzun süren GBS olgularında romatolojik hastalıklar altta yatan etiyolojik neden olabilir. Romatolojik hastalığa özgü spesifik tedavi iyileșme sürecini hızlandırarak nörolojik sekel kalma olasılığını azaltır ve rehabilitasyon sürecine büyük oranda katkı sağlar.

Anahtar Kelimeler: Guillain-Barré sendromu, rehabilitasyon, romatolojik hastalıklar, sistemik lupus eritematozus, Sjögren sendromu

\section{Introduction}

Guillain-Barré syndrome (GBS) is an acute inflammatory polyneuropathy characterized by rapidly progressive symmetrical muscle weakness and loss of deep tendon reflexes (DTR). Symptoms usually start in the lower extremities and progress to the trunk and upper extremities within days. The progression is usually symmetrical. Sensory loss, autonomic and cranial neuropathy, and neuropathic pain often accompany. Neurological signs develop over a period of several days to a month. If it is longer than one month, chronic inflammatory demyelinating polyradiculoneuropathy is mentioned (1). It is generally a middle-age disease and is more common in men (2). Influenza infection, trauma, vaccination, blood transfusion, chemotherapy, and surgical intervention that occurred weeks before the onset of symptoms are included in the etiology (3). Sjögren's syndrome (SS) is a systemic autoimmune disease characterized by lymphocytic infiltration of all exocrine glands, primarily tear and salivary glands. The incidence in women is 9 times higher, similar to other autoimmune diseases, and it peaks in the $4^{\text {th }}-5^{\text {th }}$ decades
(4). It is more common for patients with SS in advanced age to manifest with neurological complications (2). Systemic lupus erythematosus (SLE) is a chronic connective tissue disease with unknown etiology and autoimmune character, which cause immunological disorders and involving many organs and systems. Central nervous system involvement constitutes $93.1 \%$ of the neurological involvement seen in SLE. Its association with GBS is quite low, such as $0.6-1.7 \%$ (5). Here, a female patient who developed GBS after previous gastrointestinal surgery and was diagnosed with SS afterwards, and a young male patient diagnosed with SLE after the development of GBS will be discussed in the light of the literature.

\section{Case Reports}

\section{Case 1}

A 56-year-old female patient was hospitalized with the diagnosis of GBS for rehabilitation. In her history, she had a diagnosis of hiatal hernia, which was made in an external center where she applied with the

Cite this article as/Atıf: Aytekin E, Coșkun H, Pekin Doğan Y, Dede BT, Burnaz Ö, Emre U. Rheumatic Diseases Presenting with Guillain-Barré Syndrome: Sjögren's Syndrome and Systemic Lupus Erythematosus. İstanbul Med J 2020; 21(Suppl 1): 9-11.

(C) Copyright 2020 by the University of Health Sciences Turkey, Istanbul Training and Research Hospital/Istanbul Medical Journal published by Galenos Publishing House

(C) Telif Hakkı 2020 Să̆lık Bilimleri Üniversitesi istanbul Ĕgitim ve Araștırma Hastanesi/Istanbul Tıp Dergisi, Galenos Yayınevi tarafından basılmıștır. 
complaint of shortness of breath 6 years ago. Nissen fundoplication operation was applied to the patient in May 2018 due to the ongoing and increasing complaints of shortness of breath and vomiting during this period. When the complaints of vomiting started 2-3 months after the operation, the patient was referred to the general surgery clinic of our hospital, and the mesh migration was seen in the gastroscopy performed in January 2019 and the operation decision was taken. Antibiotic treatment was arranged due to the development of subcutaneous infection during follow-up. On January 29, 2019, she was consulted with the neurology clinic due to numbness around the mouth and weakness in the arms and legs. No feature was detected in the brain magnetic resonance imaging of the patient. An electroneuromyography (ENMG) study showed acute sensorimotor polyneuropathy, in which motor axonal damage to the upper and lower sensory and motor fibers is at the forefront and the sural response is maintained. The patient was transferred to the neurology service with the pre-diagnosis of GBS. Protein was found to be high $(134 \mathrm{mg} / \mathrm{dL}$ ) in the cerebrospinal fluid (CSF) examination in lumbar puncture (LP). There was no reproduction in the CSF culture. In the neurology service, the patient was given intravenous immunoglobulin (IVIG) at a dose of $0.4 \mathrm{~kg} /$ day for 5 days. After one month, the patient was transferred to our service. In the patient's neurological examination, muscle strength was $3 / 5$ in the right and left lower and upper extremities. DTR's were hypoactive. The patient's sitting balance, fine ability in the hands and grip strength were very poor. The patient was given joint range of motion (ROM), stretching, strengthening exercises, back and abdominal muscles strengthening, sitting balance training and neuromuscular electrical stimulation (NMES) (bilateral tibialis anterior, quadriceps, hamstring, wrist flexors and extensors, supraspinatus and deltoid) for four extremities in the bed. Afterwards, training was continued with standing with posterior shell and foot-ankle orthosis and walking with parallel bar.

Since the acute phase reactants were elevated during the patient's hospitalization in the physical therapy service, infection and malignancy were investigated in etiological aspect. Endoscopy, colonoscopy, abdominal and thorax computed tomography, breast ultrasonography and mammography were unremarkable. Her gynecological examination was normal. Protein electrophoresis, serum and urine immunofixation electrophoresis, tuberculosis culture was negative. Blood glucose levels were normal.

An extractable nuclear antigen profile was requested from the patient who had vague hand pain and dry mouth. The result of salivary gland biopsy taken with a pre-diagnosis of SS from the patient with anti-SSA positivity was negative.

A patient who was found to have dry eyes in the Schirmer test (right eye: $5 \mathrm{~mm}$, left eye: $5 \mathrm{~mm}$ ) was consulted with the rheumatology clinic, followed by pulse steroid ( $1000 \mathrm{mg} /$ day, 3 days IV, then oral $40 \mathrm{mg}$ prednisolone), rituximab was given as immunosuppressive and IVIG booster was given for 5 days. Sedimentation rate decreased from $103 \mathrm{~mm} /$ hour to $42 \mathrm{~mm} /$ hour. Steroid dose was reduced to 5 $\mathrm{mg} /$ day. Hydroxychloroquine was started at a dose of $200 \mathrm{mg} /$ day as a disease modifier. Muscle strength increased to $4 / 5$ level. At the end of the 4-week rehabilitation period, the patient reached the level of ambulation without the need for a device in the parallel bar. At $6^{\text {th }}$ months after discharge, the patient could ambulate without support and was independent in daily living activities. Written informed consent form was obtained from the patient.

\section{Case 2}

A 39-year-old male patient applied to the emergency service of our hospital 3 months ago with complaints of weakness in the arms and legs and numbness in the hands after acute gastroenteritis lasting about a week. In the emergency examinations and cranial imaging, the patient, who had no neurological pathology explaining the acute picture, was transferred to the neurology service with the pre-diagnosis of GBS. In the CSF examination with LP, the protein level was found to be high and no cells were detected. In ENMG, acute demyelinating polyneuropathy was detected, where motor axonal damage and message block holding motor fibers at the top and bottom were at the forefront. The patient, who received IVIG treatment at a dose of $0.4 \mathrm{~kg} /$ day for 5 days with the diagnosis of GBS, was then transferred to our service for rehabilitation. In the patient's neurological examination, muscle strength was $1 / 5$ in the right and left lower and upper extremities. The patient lacked balance of sitting, fine skill and grip in the hands. Muscle tone was hypotonic and DTRs could not be taken. In our service, training on in-bed positioning, ROM exercises, and sitting balance was started. Strengthening exercises were given to upper and lower extremities, abdominal and back muscles. NMES was applied to bilateral quadriceps, tibialis anterior, hamstring, finger flexor and extensor, wrist flexor and extensor, deltoid, supraspinatus muscles.

After the antinuclear antibody, anti-dsDNA and anti-Ro antibodies of the patient who was examined for vasculitis tests as part of the etiological examination resulted positive, he was consulted with the rheumatology clinic. The patient, who was diagnosed with SLE with SLE International Cooperation Classification Criteria, was continued with $60 \mathrm{mg} /$ day prednisolone after pulse steroid for 7 days. Considering that SLE had neurological involvement, rituximab and hydroxychloroquine $200 \mathrm{mg} 2 \times 1 /$ day was started. Antiviral therapy (entecavir) was started with the consultation of infectious diseases clinic to the patient with accompanying anti-HBclgG positivity. In addition, plasmapheresis with 10 sessions of albumin was applied to the patient. With the response to the treatment, the steroid dose was reduced to $5 \mathrm{mg} /$ day. Monthly IVIG booster application continued. After 3 months of rehabilitation, the patient reached the level of ambulation in the parallel bar. Written informed consent form was obtained from the patient.

\section{Discussion}

Neurological involvement is $20 \%$ in patients with SS. Interestingly; neurological signs may precede the symptoms of sicca. Various types of peripheral neuropathy have been identified in patients with SS [symmetrical sensorimotor polyneuropathy (most common), symmetrical sensory neuropathy, sensory neuronopathy, autonomic neuropathy, mononeuropathy, mononeuropathy multiplex, and cranial neuropathy (especially trigeminal neuropathy)]. The variety of clinical symptoms may cause delays in the diagnosis of SS (2). Association of SS and GBS is rare in the literature $(6,7)$. In a study that tracked cases that developed GBS after surgery, the average age of patients was 55 , and the 
proportion of male patients was $56.5 \%$. The average time between the surgical procedure and the development of GBS has been reported as 8 weeks. It has been observed that the risk of GBS is increased in patients with malignancy and comorbid autoimmune diseases. In the same study, association with autoimmune diseases was found in $10 \%$ of cases and a diagnosis of SS was found in 1.5\% of cases. As a surgical procedure, it was most frequently (32.1\%) associated with gastrointestinal surgery (3). The age of our patient was compatible with this case series. The diagnosis of SS and the gastrointestinal surgical procedure performed 2 months ago were considered as risk factors and indicators of poor prognosis.

1999 American College of Rheumatology identified 7 types of peripheral neuropathy associated with SLE: Acute inflammatory demyelinating polyradiculoneuropathy GBS, autonomic disorder, mononeuropathy, myasthenia gravis, cranial neuropathy, plexopathy, polyneuropathy. Coexistence of GBS and SLE is extremely rare among these. SLE is an autoimmune systemic disease with complex and varied clinical symptoms. Since GBS-like acute axonal neuropathies are rare in SLE patients, controlled clinical studies are insufficient. However, the relationship between SLE and GBS has been proven with the data in the literature (5)

In conclusion, it should be kept in mind in terms of early initiation of treatment and patient prognosis that there may be accompanying autoimmune rheumatologic disease in patients with GBS diagnosis. Anamnesis specific to autoimmune diseases, especially SS and SLE diseases, should be questioned and advanced laboratory examinations should be performed especially in patients with GBS, which are refractory and tend to become chronic at an advanced age.

\section{Ethics}

Informed Consent: Written informed consent form was obtained from the patient.
Peer-review: Internally peer-reviewed.

Authorship Contributions: Surgical and Medical Practices - E.A., Y.P.D., B.T.D., U.E.; Concept - E.A., Y.P.D., B.T.D., U.E.; Design - E.A., Y.P.D., Ö.B., U.E.; Data Collection or Processing - E.A., H.C., B.T.D., Ö.B.; Analysis or Interpretation - E.A., H.C., Y.P.D., U.E.; Literature Search - E.A., H.C., Ö.B.; Writing - E.A., H.C.

Conflict of Interest: No conflict of interest was declared by the authors.

Financial Disclosure: The authors declared that this study received no financial support.

\section{References}

1. Varkal MA, Yıldız E, Yıldız I, Aydınlı N, Ünüvar E. Çocukluk Çağında GuillainBarré Sendromu. Çocuk Dergisi 2015; 15: 89-98.

2. Lin YK, Yang FC, Liu FC, Lee JT, Sung YF. Co-Cccurrence of Guillain-Barre Syndrome and Primary Sjögren Syndrome in an Elderly Woman. Acta Neurol Taiwan 2016; 25: 83-7.

3. Nagarajan E, Rubin MN, Wijdicks E, Hocker S. Guillain-Barré syndrome after surgical procedures. Predisposing factors and outcome. Neurol Clin Pract 2017; $7:$ 1-9.

4. Vitali C, Bombardieri S, Jonsson R, Moutsopoulos HM, Alexander EL, Carsons $S E$, et al. Classification criteria for Sjögren's syndrome: a revised version of the European criteria proposed by the American-European Consensus Group. Ann Rheum Dis 2002; 61: 554-8.

5. Bortoluzzi A, Silvagni E, Furini F, Piga M, Govoni M. Peripheral nervous system involvement in systemic lupus erythematosus: a review of the evidence. Clin Exp Rheumatol 2019; 37: 146-55

6. Pryszmont M, Sierakowski S, Popławska T, Domysławska I, Pryszmont J, Pawlak-Tumiel B. Guillain-Barré syndrome in a patient with primary sicca syndrome. Neurol Neurochir Pol 2000; 34: 1235-41.

7. Awad A, Mathew S, Katirji B. Acute motor axonal neuropathy in association with Sjögren syndrome. Muscle Nerve 2010; 42: 828-30. 